\title{
Optimization for the Production of Cellulase Enzyme from Municipal Solid Waste Residue by Two Novel Cellulolytic Fungi
}

\author{
S. P. Gautam, ${ }^{1}$ P. S. Bundela, ${ }^{2}$ A. K. Pandey, ${ }^{3}$ Jamaluddin Khan, $^{4}$ M. K. Awasthi, ${ }^{2}$ \\ and S. Sarsaiya ${ }^{2}$ \\ ${ }^{1}$ Central Pollution Control Board, New Delhi, India \\ ${ }^{2}$ Regional Office, M. P. Pollution Control Board, Vijay Nagar, Jabalpur, Madhya Pradesh, India \\ ${ }^{3}$ Mycological Research Laboratory, Department of Biological Sciences, Rani Durgavati University, Jabalpur, Madhya Pradesh, India \\ ${ }^{4}$ Yeast and Mycorrhiza Biotechnology Laboratory, Department of Biological Sciences, Rani Durgavati University, \\ Jabalpur, Madhya Pradesh, India
}

Correspondence should be addressed to S. Sarsaiya, surendra_sarsaiya@yahoo.co.in

Received 13 November 2010; Accepted 24 December 2010

Academic Editor: Triantafyllos Roukas

Copyright (C) 2011 S. P. Gautam et al. This is an open access article distributed under the Creative Commons Attribution License, which permits unrestricted use, distribution, and reproduction in any medium, provided the original work is properly cited.

\begin{abstract}
The main purpose of this study is to reduce the production cost of cellulase by optimizing the production medium and using an alternative carbon source such as municipal solid waste residue. In the present investigation, we aim to isolate the two novel cellulase producing fungi (Aspergillus niger and Trichoderma sp.) from municipal solid waste. Municipal solid waste residue (4-5\% $(\mathrm{w} / \mathrm{v}))$ and peptone and yeast extract $(1.0 \%(\mathrm{w} / \mathrm{v}))$ were found to be the best combination of carbon and nitrogen sources for the production of cellulase by $A$. niger and Trichoderma sp. Optimum temperature and $\mathrm{pH}$ of the medium for the cellulase production by $A$. niger were $40^{\circ} \mathrm{C}$ and $6-7$, whereas those for the production of cellulase by Trichoderma sp. were $45^{\circ} \mathrm{C}$ and 6.5 . Cellulase production from A. niger and Trichoderma sp. can be an advantage as the enzyme production rate is normally higher as compared to other fungi.
\end{abstract}

\section{Introduction}

Ethanol production from municipal solid waste biomass is emerging as one of the most important technologies for sustainable fuels. major constrains in enzymatic hydrolysis of cellulosic materials for the production of fermentation sugar are low productivity and the cost of cellulases [1]. Municipal solid waste (MSW) is the largest group of waste present on this planate causing environmental pollutions [2]. It was estimated that the photosynthetic material annually with respect to carbon of which about $50 \%$ is cellulose. It is a fibrous, insoluble, high molecular weight, crystalline polysaccharides composted of repeating D-glucose units linked by $\beta-1,4-$ glucosidic bonds and being the most abundant carbohydrate polymer on earth $[3,4]$. Cellulases are consortium of free enzymes which comprise of endoglucanases $(\beta-1,4-\mathrm{D}$ glucan-4-glucanohydrolase, EC 3.2.1.4, carboxymethyl cellulase, EC), exoglucanases ( $\beta$-1,4-D-glucan-4-glucohydrolase, EC 3.2.1.91, cellobiohydrolase, $\mathrm{CBH})$, and cellobiases $(\beta-\mathrm{D}$ glucoside glucohydrolase, EC 3.2.1.21, $\beta$-1,4-D-glucosidase) which are found in many of the 57 glycosyl hydrolase families [5]. The right proportion of these enzyme acts synergistically for maximum saccharification. Endoglucanase cleaves internal $\beta$-1,4-glucan chain links in cellulose randomly [6] and opens the molecules for cellobiohydrolases which hydrolyze the bonds at nonreducing end of crystalline cellulosic chain producing cellobiose cellobiases which split the disaccharide units and convert cellobiose into glucose and thus complete the cellulolysis [7]. MSW containing organic substances is an ideal habitat for different species of fungi. Cellulolytic fungi isolated from this source have been used to convert cellulosic materials into valuable compounds such as ethanol and organic acid. Some of these fungi are mesophiles whereas others are thermotolerant. Usually the thermotolerant elaborate enzymes are more active at high temperature and more thermostable than enzymes produced by their mesophilic counterparts. The biological degradation of cellulose has a great importance in the activity of living system. Many cellulolytic waste products which otherwise are inedible not potable for human consumption are converted into 
useful products by the aid of microorganisms. Cellulolytic organism can convert cellulose in various economically important products and monomeric sugars $[8,9]$, single cell protein [10], antibiotics [11], and compost [12] to every day use for man. Utilization of cellulosic material is thought in recent years to contribute to the production of food and energy [13].

Microbial enzymes have the enormous advantage of being able to be produced in large quantities by established fermentation techniques. Enzyme production is closely controlled in microorganisms and therefore, to improve its productivity these controls can be exploited and modified. Cellulase yields appear to depend on a complex relationship involving a variety of factors like $\mathrm{pH}$, temperature, incubation period, cations, carbon, and nitrogen sources $[14,15]$. To establish a successful fermentation process, it is necessary to make the microorganism for overproduction of the desired metabolite. An elaborate investigation is therefore, required to establish the optimum condition to scale up enzyme production in an individual fermentation process. Several researchers have shown that the production costs of cellulase are tightly associated with the productivity of enzyme producing microbial strains [16-19]. Such process would help alleviate shortages of food and animal feeds, solve modern waste disposal problem, and diminish man's dependence on fossil fuels by providing a convenient and renewable source of energy in the form of glucose which can be used for the production of ethanol, organic acids, and other chemicals [20].

In this investigation, a cellulase producing strain of A. niger and Trichoderma sp., isolated from municipal solid waste, were subjected to optimization of media and cultivation parameters for cellulase production.

\section{Materials and Methods}

2.1. Collection of Sample. Municipal solid waste samples were collected from different localities of Jabalpur. It was taken by means of sterilized spatulas and collected in sterile polythene bags. The samples were then brought to the laboratory for Microbiological study.

2.2. Isolation of Fungi. Municipal solid waste was collected for the isolation of fungi. One gram was transferred to aliquots of $9 \mathrm{~mL}$ sterile distilled water in test tube. It was shaken vigorously at constant speed for $15 \mathrm{~min}$. The MSW suspension was then subjected to serial dilutions from the appropriate plate in duplicate. The plates were incubated for 5 days at $28^{\circ} \mathrm{C}$. The well-grown spreaded single colonies were picked up and subcultured on potato dextrose agar slants.

2.3. Screening for Cellulase Enzyme. Municipal solid waste associated fungi were tested for their ability to produce the hydrolytic enzymes: cellulase in a plate assay method using $1 \%$ carboxymethyl cellulose in a basal salt media, respectively, according to [21] at the incubation period, $0.1 \%$ congo red solution was added and counterstained with $1 \mathrm{M}$ $\mathrm{NaCl}$ for $15-20 \mathrm{~min}$. The zone of cellulose hydrolysis was appeared as a clear area around the colony.
2.4. Production of Cellulase Enzyme. Strains presenting large clearing zones in congo red test were used for enzyme production on basal salt medium containing $1 \%$ cellulose as a sole carbon source [22]. Stationary state technique was used and $150 \mathrm{~mL}$ Erlenmeyer flask filled with $50 \mathrm{~mL}$ of the medium. Each flask was inoculated with two discs $(7 \mathrm{~mm}$ diameters) cut from the periphery of 4-day-old culture of Aspergillus niger and Trichoderma sp. actively growing on PDA plates. The flasks were then incubated at $30^{\circ} \mathrm{C}$ in stationary state.

2.5. Enzyme Assay. Filter paper activity (FPase) for total cellulase activity in the culture filtrate was determined according to the standard method [21]. Aliquots of appropriately diluted cultured filtrate as enzyme source were added to whatman no. 1 filter paper strip $(1 \times 6 \mathrm{~cm} ; 50 \mathrm{mg})$ immersed in one milliliter of $0.05 \mathrm{M}$ Sodium citrate buffer of pH 5.0. After incubation at $50 \pm 2^{\circ} \mathrm{C}$ for $1 \mathrm{hr}$, the reducing sugar released was estimated by dinitrosalicylic acid (DNS) method [23]. One unit of filter paper (FPU) activity was defined as the amount of enzyme releasing $1 \mu$ mole of reducing sugar from filter paper per $\mathrm{ml}$ per min. Endoglucanase activity (CMCase) was measured using a reaction mixture containing $1 \mathrm{~mL}$ of $1 \%$ carboxymethyl cellulose (CMC) in $0.5 \mathrm{M}$ citrate acetate buffer ( $\mathrm{pH}$ 5.0) and aliquots of suitably diluted filtrate. The reaction mixture was incubated at $50 \pm 2^{\circ} \mathrm{C}$ for $1 \mathrm{~h}$, and the reducing sugar produced was determined by DNS method. $\beta$-glucosidase activity was assayed by the method of [24]. One unit (IU) of endoglucanase activity was defined as the amount of enzyme releasing $1 \mu$ mole of reducing sugar per min.

\subsection{Optimization of Culture Conditions for Enzyme Production}

2.6.1. Effect of $p H$ on Enzyme Production. To determine optimal $\mathrm{pH}$, A. niger and Trichoderma sp. were cultivated in a $150 \mathrm{~mL}$ flask containing $50 \mathrm{~mL}$ optimized medium with different $\mathrm{pH}$ ranges from 3.0 to 9.0. The $\mathrm{pH}$ of the medium was adjusted by using $1 \mathrm{~N} \mathrm{HCl}$ or $1 \mathrm{~N} \mathrm{NaOH}$. The flasks were kept in stationary stage at $37^{\circ} \mathrm{C}$ for 5 days of cultivation.

2.6.2. Effect of Temperature on Enzyme Production. In order to determine the effective temperature for cellulase production by the A. niger and Trichoderma sp., fermentation was carried out at $10^{\circ} \mathrm{C}$ intervals in the range of 20 to $80 \pm 2^{\circ} \mathrm{C}$.

2.6.3. Effect of Incubation Period on Enzyme Production. Fermentation period was an important parameter for enzyme production by $A$. niger and Trichoderma sp. In this study, fermentation experiment was carried out up to 7 days and production rate was measured at $24 \mathrm{~h}$ intervals.

2.6.4. Effect of Carbon Sources on Enzyme Production. Effects of various carbon compounds namely, cellulose, CMC, glucose, sucrose, and maltose were used for studying. The broth was distributed into different flasks and 0.5 to $3.0 \%$ of each carbon sources were then added before inoculation 
of the strain and after culture inoculation, the flasks were incubated for 5 days at $45 \pm 2^{\circ} \mathrm{C}$.

2.6.5. Effect of Nitrogen Sources on Enzyme Production. In the present study, we aim to detect the appropriate nitrogen source for cellulase production by the A. niger and Trichoderma sp. The fermentation medium was supplemented with organic and inorganic compounds (peptone, beef extract, ammonium nitrate, sodium nitrate, and yeast extract) at 0.5 to $3.0 \%$ level, replacing the prescribed nitrogen source of the fermentation medium.

2.6.6. Effect of Municipal Solid Waste Residue on Enzyme Production. In the present study, we aim to determine the appropriate concentration of municipal solid waste residue for cellulase production by the A. niger and Trichoderma sp. The fermentation medium was supplemented with municipal solid waste residue at 1.0 to $6.0 \%$ level, replacing the prescribed carbon source of the fermentation medium.

2.7. Statistical Analysis. Data presented on the average of three replicates $( \pm \mathrm{SE})$ are obtained from there independent experiments.

\section{Results and Discussion}

3.1. Screening of Fungi for Cellulase Activity. Screenings of fungi for their cellulase activity were carried out by the hydrolysis of substrate incorporating in the basal salt medium. After an incubation period, enzyme activities were detected by the appearance of zones either by substrate clearances or coloration and discoloration around the fungal colonies. A. niger and Trichoderma sp. were showed the highest zone around the colony, used for further study.

\subsection{Optimization of Culture Conditions for \\ Enzyme Production}

3.2.1. Effect of $\mathrm{pH}$ on Enzyme Production. There exists a strong influence of initial $\mathrm{pH}$ of the medium on enzyme production. To evaluate the effects of $\mathrm{pH}$ value in substrate on cellulase synthesis, the $\mathrm{pH}$ values were adjusted by the addition of $\mathrm{HCl}$ or $\mathrm{NaOH}$ to $3.0,4.0,5.0,7.0,8.0$, and 9.0. The results shown in Figures 1 and 5 showed that the production of exoglucanase $(1.76 \& 2.16 \mathrm{U} / \mathrm{mL})$, endoglucanase $(1.25 \& 1.94 \mathrm{U} / \mathrm{mL})$, and $\beta$-glucosidase $(1.44$ $\& 1.71 \mathrm{U} / \mathrm{mL}$ ) by $A$. niger and Trichoderma sp. was found between 6-7 and 5-6 pH. The optimum pHs for cellulase activity were found at $\mathrm{pH} 6.5$. The enzyme activity gradually increased when increasing the $\mathrm{pH}$ up to the optimum followed by a gradual full in activity. It was also noted that the enzyme activity was stable at $\mathrm{pH}$ range of 5.0-8.0. Effect of $\mathrm{pH}$ on cellulase production by these fungi supports the findings of [25] who reported that CMCase, Avicelase, and FPase activities exhibit a $\mathrm{pH}$ optimum of approximately 4 , while the $\mathrm{pH}$ optimum of $\beta$-glucosidase was between $\mathrm{pH}$ 5-6.

3.2.2. Effect of Temperature on Enzyme Production. The effect of temperature on cellulase activity was determined by

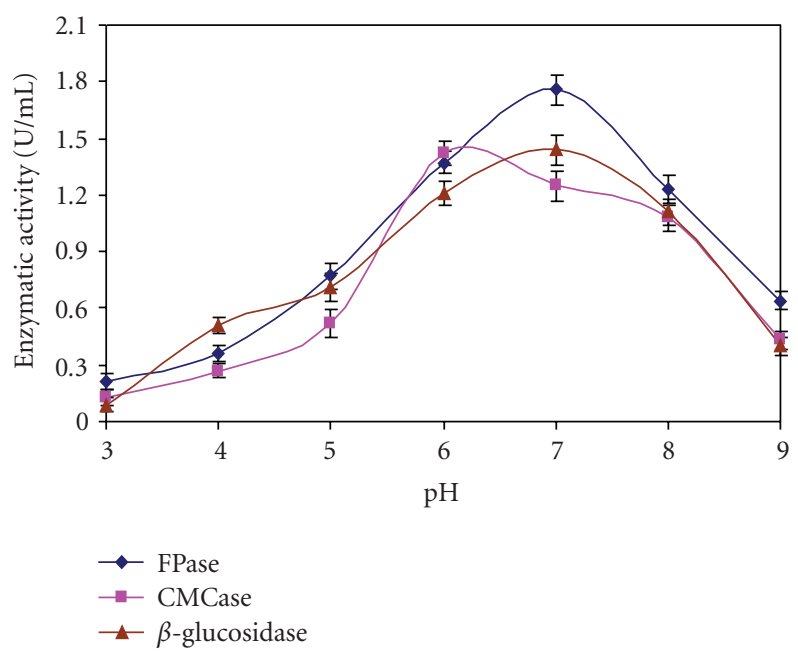

Figure 1: Effect of $\mathrm{pH}$ on cellulase production $(\mathrm{U} / \mathrm{mL})$ by $A$. niger.

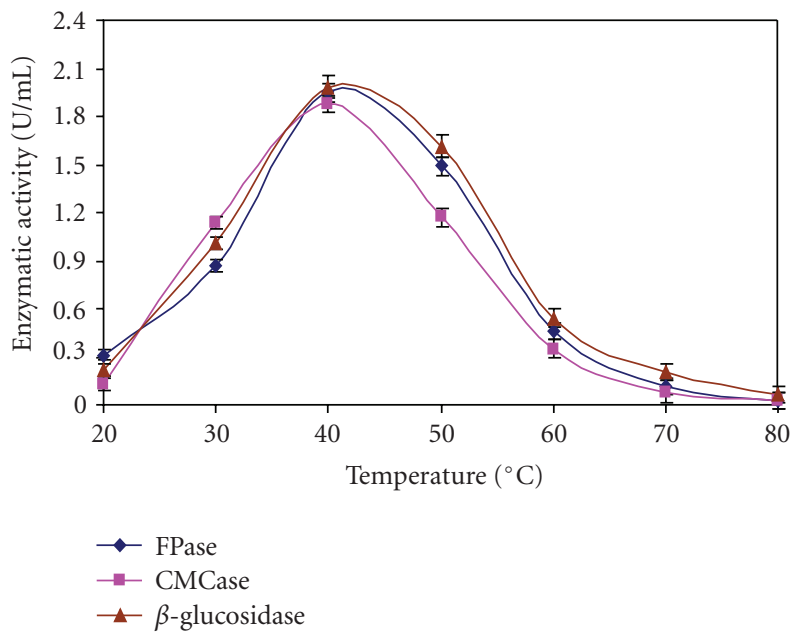

FIGURE 2: Effect of temperature on cellulase production $(\mathrm{U} / \mathrm{mL})$ by A. niger.

incubating the flask at a range of temperature of $20,30,40$, $50,60,70$, and $80^{\circ} \mathrm{C}$. The results of the test made at different temperatures value showed that the optimal temperature for exoglucanase $(1.95 \mathrm{U} / \mathrm{mL})$ and endoglucanase activity $(1.88 \mathrm{U} / \mathrm{mL})$ produced by $A$. niger was between 40 and $50^{\circ} \mathrm{C}$ (Figure 2), while the optimum temperature for $\beta$-glucosidase activity $(1.98 \mathrm{U} / \mathrm{mL})$ between 45 and $55^{\circ} \mathrm{C}$. Due to high temperature (above $65^{\circ} \mathrm{C}$ ), the results showed that the enzyme activity was decreased when the temperature increased above $65^{\circ} \mathrm{C}$. However, maximum enzyme production by Trichoderma sp. was found to be $1.95 \mathrm{U} / \mathrm{mL}$ exoglucanase, $1.88 \mathrm{U} / \mathrm{mL}$ endoglucanase and $1.88 \beta$-glucosidase activity between $40-50^{\circ} \mathrm{C}$ (Figure 6). Many workers have reported different temperatures for maximum cellulase production either in flask or in fermentor studies using Aspergillus sp. and Trichoderma sp. suggesting that the optimal temperature for cellulase production also depends on the strain variation of the microorganism $[26,27]$. 


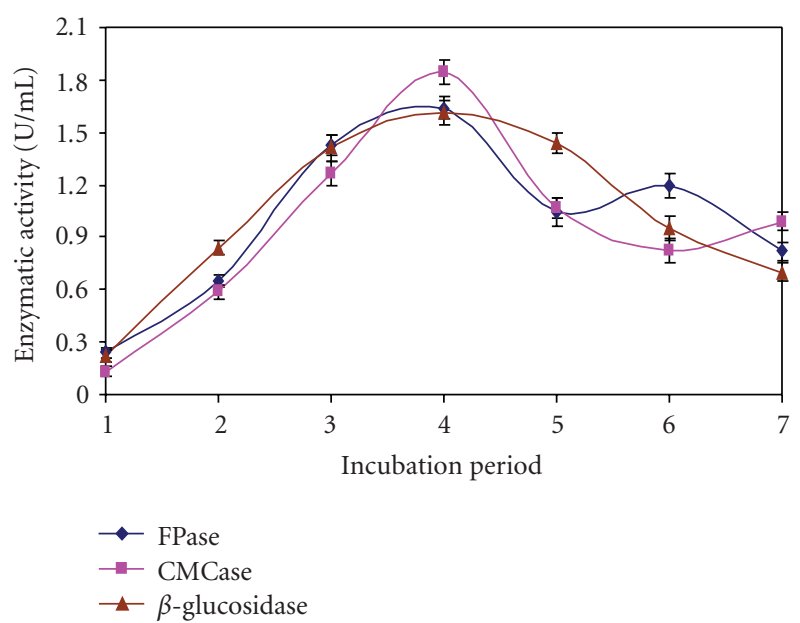

FIGURE 3: Effect of incubation period on cellulase production $(\mathrm{U} / \mathrm{mL})$ by $A$. niger.

3.2.3. Effect of Incubation Period on Enzyme Production. Aspergillus niger was inoculated into basal salt medium in $150 \mathrm{~mL}$ conical flask and incubated at $45 \pm 2^{\circ} \mathrm{C}$ for a period of 7 days. The cellulase activity was measured at regular intervals. However, the maximum yield of exoglucanase $(1.64 \mathrm{U} / \mathrm{mL})$ and endoglucanase $(1.84 \mathrm{U} / \mathrm{mL})$ activity was obtained after 4 days. However, maximum $\beta$-glucosidase $(1.61 \mathrm{U} / \mathrm{mL})$ activity was shown after $3-5$ days incubation in Figures 3 and 7. To determine the optimum incubation period for enzyme production by Trichoderma sp., the highest amount of glucose was recorded on 5th day. The incubation period is directly related to the production of enzyme and other metabolic up to a certain extent. A. niger and Trichoderma sp. showed the most active cellulolytic species along different incubation period. The incubation periods to achieve peak cellulase activity by the isolate A. niger and Trichoderma sp. were 4th and 6th days which was suitable for commercial point of view [28]. It might be due to the depletion of nutrients in the medium which stressed the fungal physiology resulting in the inactivation of secretary machinery of the enzymes [29].

3.2.4. Effect of Carbon Sources on Enzyme Production. Carbon sources play a vital role in the cell metabolism and synthesis of cellulase. The effect of carbon sources on the production of enzyme by A. niger and Trichoderma sp. was investigated. Carbon sources tested for production of cellulase enzyme by $A$. niger were glucose, sucrose, cellulose, carboxymethyl cellulose, and maltose ranging from 0.5 to $3.0 \%(\mathrm{w} / \mathrm{v})$. Cellulose and CMC were found to be the best carbon sources for enzyme production by $A$. niger as shown in Table 1. However, the maximum production of exoglucanase $(1.97 \mathrm{U} / \mathrm{mL})$, endoglucanase $(1.67 \mathrm{U} / \mathrm{mL})$, and $\beta$-glucosidase $(2.31 \mathrm{U} / \mathrm{mL})$ was obtained in culture containing $1.0 \%$ cellulose. Among the different carbon sources used, the CMC was the second best carbon source (1.0\%) for cellulase production by $A$. niger followed by sucrose, glucose, and maltose

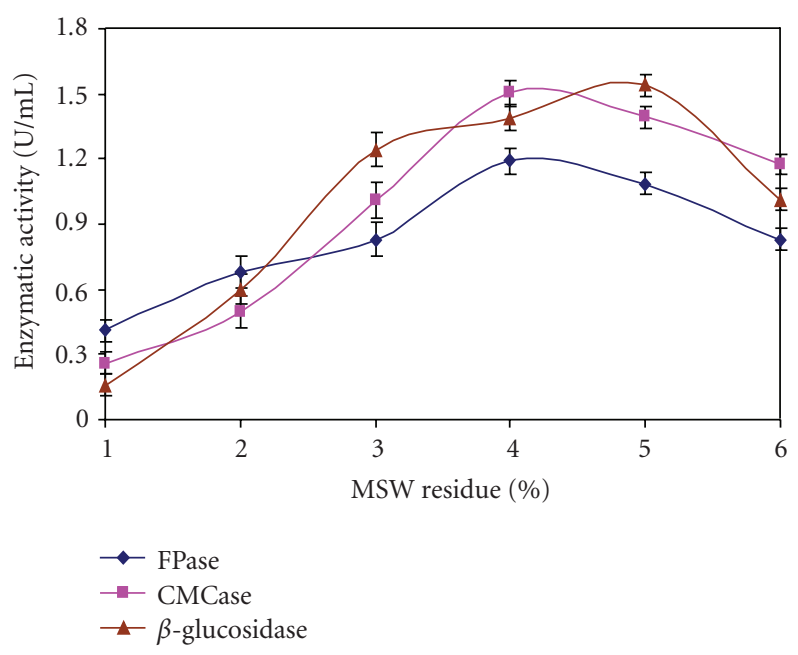

FIGURE 4: Effect of MSW residue on cellulase production $(\mathrm{U} / \mathrm{mL})$ by $A$. niger.

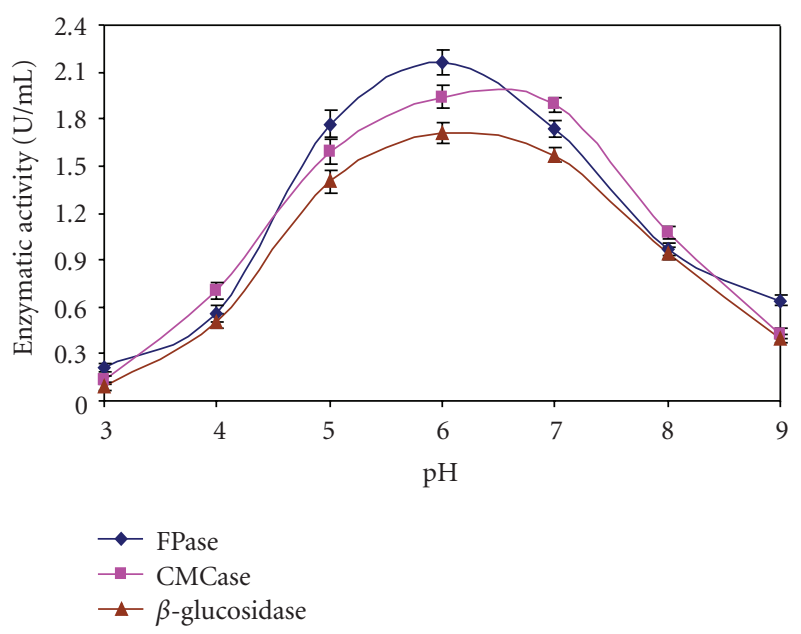

Figure 5: Effect of $\mathrm{pH}$ on cellulase production $(\mathrm{U} / \mathrm{mL})$ by Trichoderma sp.

(Table 1), while sucrose (1.0\%) was found to be the best carbon for cellulase production (exoglucanase $(2.68 \mathrm{U} / \mathrm{mL}$ ), endoglucanase $(2.17 \mathrm{U} / \mathrm{mL})$ and $\beta$-glucosidase $(2.06 \mathrm{U} / \mathrm{mL})$ ) by Trichoderma sp. followed by glucose, cellulose maltose, and CMC. Cellulase production increased with increases in initial sugar concentration from 1.0 to $1.5 \%$ (Table 3) while further increases in sugar concentration slightly reduced the yield. Cellulase production increased with increases in initial sugar concentration from 1.0 to $1.5 \%$, while further increases in sugar concentration slightly reduced the yield. Reference [30] also reported that maximum yields of cellulase were obtained on $1 \%$ different carbon substrate using $T$. viride. Cellulase production commended on reaching nitrogenlimiting conditions and the yield of cellulase decreased when excess peptone was presented; various inorganic nitrogen sources have been optimized by different workers for cellulase production $[22,31]$. 
TABLE 1: Effect of carbon sources (\%) on cellulase production $(\mathrm{U} / \mathrm{mL})$ by $A$. niger.

\begin{tabular}{|c|c|c|c|c|c|c|c|c|}
\hline \multicolumn{2}{|c|}{ Conc. (\%) } & \multicolumn{2}{|r|}{0.5} & \multirow{2}{*}{$\frac{1.0}{1.88 \pm 0.07}$} & \multirow{2}{*}{$\frac{1.5}{1.32 \pm 0.04}$} & \multirow{2}{*}{$\begin{array}{c}2.0 \\
0.91 \pm 0.05\end{array}$} & \multirow{2}{*}{$\begin{array}{c}2.5 \\
0.54 \pm 0.03\end{array}$} & \multirow{2}{*}{$\frac{3.0}{0.37 \pm 0.02}$} \\
\hline & & 1 & $0.41 \pm 0.02$ & & & & & \\
\hline & Glucose & 2 & $0.26 \pm 0.02$ & $1.61 \pm 0.05$ & $1.11 \pm 0.03$ & $0.82 \pm 0.04$ & $0.51 \pm 0.05$ & $0.29 \pm 0.03$ \\
\hline & & 3 & $0.21 \pm 0.02$ & $1.90 \pm 0.05$ & $1.39 \pm 0.04$ & $0.71 \pm 0.04$ & $0.48 \pm 0.03$ & $0.20 \pm 0.02$ \\
\hline & & 1 & $0.09 \pm 0.02$ & $1.13 \pm 0.05$ & $0.91 \pm 0.04$ & $0.76 \pm 0.04$ & $0.39 \pm 0.03$ & $0.13 \pm 0.03$ \\
\hline & Maltose & 2 & $0.18 \pm 0.02$ & $1.37 \pm 0.06$ & $1.24 \pm 0.04$ & $0.64 \pm 0.05$ & $0.34 \pm 0.03$ & $0.22 \pm 0.02$ \\
\hline & & 3 & $0.41 \pm 0.02$ & $1.84 \pm 0.06$ & $1.71 \pm 0.04$ & $1.11 \pm 0.04$ & $0.69 \pm 0.02$ & $0.40 \pm 0.02$ \\
\hline & & 1 & $0.49 \pm 0.02$ & $2.07 \pm 0.05$ & $1.55 \pm 0.05$ & $0.73 \pm 0.04$ & $0.39 \pm 0.04$ & $0.18 \pm 0.02$ \\
\hline \multirow[t]{8}{*}{ Different carbon sources } & Sucrose & 2 & $0.11 \pm 0.06$ & $1.81 \pm 0.03$ & $1.11 \pm 0.04$ & $0.76 \pm 0.04$ & $0.35 \pm 0.03$ & $0.24 \pm 0.02$ \\
\hline & & 3 & $0.22 \pm 0.02$ & $1.76 \pm 0.05$ & $1.51 \pm 0.04$ & $0.82 \pm 0.04$ & $0.27 \pm 0.02$ & $0.10 \pm 0.03$ \\
\hline & & 1 & $0.23 \pm 0.02$ & $1.97 \pm 0.07$ & $1.64 \pm 0.05$ & $0.77 \pm 0.04$ & $0.42 \pm 0.04$ & $0.26 \pm 0.03$ \\
\hline & Cellulose & 2 & $0.15 \pm 0.02$ & $1.67 \pm 0.03$ & $0.73 \pm 0.04$ & $0.54 \pm 0.04$ & $0.29 \pm 0.02$ & $0.11 \pm 0.05$ \\
\hline & & 3 & $0.21 \pm 0.02$ & $2.31 \pm 0.07$ & $0.76 \pm 0.04$ & $0.61 \pm 0.04$ & $0.38 \pm 0.02$ & $0.29 \pm 0.02$ \\
\hline & & 1 & $0.19 \pm 0.02$ & $1.88 \pm 0.05$ & $1.01 \pm 0.04$ & $0.73 \pm 0.04$ & $0.48 \pm 0.03$ & $0.31 \pm 0.02$ \\
\hline & Carboxymethyl cellulose & 2 & $0.15 \pm 0.02$ & $1.10 \pm 0.05$ & $1.01 \pm 0.04$ & $0.51 \pm 0.04$ & $0.34 \pm 0.03$ & $0.19 \pm 0.03$ \\
\hline & & 3 & $0.33 \pm 0.02$ & $2.09 \pm 0.07$ & $1.27 \pm 0.04$ & $0.81 \pm 0.05$ & $0.57 \pm 0.02$ & $0.23 \pm 0.02$ \\
\hline
\end{tabular}

1-FPase, 2-CMCase \& 3- $\beta$-glucosidase.

TABLE 2: Effect of nitrogen sources (\%) on cellulase production (U/mL) by A. niger.

\begin{tabular}{|c|c|c|c|c|c|c|c|c|}
\hline \multicolumn{2}{|c|}{ Conc. } & \multicolumn{2}{|r|}{0.5} & \multirow{2}{*}{$\frac{1.0}{1.78 \pm 0.06}$} & \multirow{2}{*}{$\frac{1.5}{1.27 \pm 0.04}$} & \multirow{2}{*}{$\frac{2.0}{0.87 \pm 0.04}$} & \multirow{2}{*}{$\frac{2.5}{0.61 \pm 0.03}$} & \multirow{2}{*}{$\begin{array}{c}3.0 \\
0.41 \pm 0.02\end{array}$} \\
\hline & & 1 & $0.19 \pm 0.02$ & & & & & \\
\hline & Peptone & 2 & $0.06 \pm 0.02$ & $1.44 \pm 0.05$ & $1.08 \pm 0.04$ & $0.62 \pm 0.04$ & $0.43 \pm 0.03$ & $0.38 \pm 0.03$ \\
\hline & & 3 & $0.27 \pm 0.02$ & $1.97 \pm 0.05$ & $1.61 \pm 0.05$ & $0.97 \pm 0.04$ & $0.51 \pm 0.03$ & $0.43 \pm 0.05$ \\
\hline & & 1 & $0.16 \pm 0.02$ & $1.71 \pm 0.07$ & $1.43 \pm 0.05$ & $0.95 \pm 0.04$ & $0.69 \pm 0.02$ & $0.53 \pm 0.03$ \\
\hline & Yeast extract & 2 & $0.09 \pm 0.02$ & $1.68 \pm 0.03$ & $1.34 \pm 0.04$ & $0.72 \pm 0.04$ & $0.56 \pm 0.07$ & $0.33 \pm 0.05$ \\
\hline & & 3 & $0.31 \pm 0.02$ & $1.89 \pm 0.05$ & $1.43 \pm 0.04$ & $1.05 \pm 0.04$ & $0.73 \pm 0.02$ & $0.51 \pm 0.04$ \\
\hline & & 1 & $0.64 \pm 0.02$ & $1.78 \pm 0.05$ & $1.27 \pm 0.04$ & $0.87 \pm 0.04$ & $0.61 \pm 0.03$ & $0.41 \pm 0.05$ \\
\hline \multirow[t]{8}{*}{ Different nitrogen sources } & Beef extract & 2 & $0.16 \pm 0.02$ & $1.54 \pm 0.07$ & $1.08 \pm 0.04$ & $0.62 \pm 0.05$ & $0.43 \pm 0.03$ & $0.38 \pm 0.02$ \\
\hline & & 3 & $0.27 \pm 0.02$ & $1.97 \pm 0.03$ & $1.61 \pm 0.04$ & $0.97 \pm 0.04$ & $0.51 \pm 0.07$ & $0.43 \pm 0.05$ \\
\hline & & 1 & $0.09 \pm 0.02$ & $1.02 \pm 0.04$ & $0.83 \pm 0.03$ & $0.43 \pm 0.04$ & $0.37 \pm 0.02$ & $0.20 \pm 0.02$ \\
\hline & Ammonium nitrate & 2 & $0.08 \pm 0.02$ & $0.97 \pm 0.03$ & $0.73 \pm 0.04$ & $0.54 \pm 0.04$ & $0.29 \pm 0.07$ & $0.11 \pm 0.05$ \\
\hline & & 3 & $0.18 \pm 0.02$ & $0.99 \pm 0.03$ & $0.84 \pm 0.04$ & $0.63 \pm 0.04$ & $0.41 \pm 0.07$ & $0.32 \pm 0.05$ \\
\hline & & 1 & $0.12 \pm 0.02$ & $1.62 \pm 0.05$ & $1.03 \pm 0.04$ & $0.89 \pm 0.04$ & $0.55 \pm 0.02$ & $0.47 \pm 0.05$ \\
\hline & Sodium nitrate & 2 & $0.10 \pm 0.02$ & $1.39 \pm 0.06$ & $1.01 \pm 0.04$ & $0.72 \pm 0.04$ & $0.44 \pm 0.03$ & $0.21 \pm 0.02$ \\
\hline & & 3 & $0.41 \pm 0.02$ & $1.84 \pm 0.05$ & $1.21 \pm 0.04$ & $0.79 \pm 0.05$ & $0.61 \pm 0.04$ & $0.33 \pm 0.02$ \\
\hline
\end{tabular}

1-FPase, 2-CMCase \& 3- $\beta$-glucosidase.

3.2.5. Effect of Nitrogen Sources on Enzyme Production. The effect of different nitrogen sources on the production of cellulase enzyme by $A$. niger and Trichoderma sp. was investigated. The nitrogen sources tested ranged from 0.5 to $3.0 \%(\mathrm{w} / \mathrm{v})$ peptone, beef extract, yeast extract, ammonium nitrate, and sodium nitrate. The results in Table 2 showed that a concentration of $1.0 \%$ peptone, beef extract, and yeast extract led to maximum production of cellulase enzyme. Among different nitrogen sources, the highest cellulase production (exoglucanase $(1.78 \mathrm{U} / \mathrm{mL}$ ), endoglucanase $(1.44 \mathrm{U} / \mathrm{mL})$, and $\beta$-glucosidase $(1.97 \mathrm{U} / \mathrm{mL})$ ) was reported from $1.0 \%$ peptone and production decreased significantly below and above this concentration by $A$. niger. Peptone produced maximum cellulase followed by ammonium nitrate and beef extract while yeast extract and sodium nitrate produced almost same, lesser, quantity of cellulase by $A$. niger while nitrogen sources had a marked effect on enzyme produced by Trichoderma sp. The maximum enzyme activities were obtained with yeast extract (1.0\%) which brought about an improvement in all the three cellulase components, including exoglucanase $(2.40 \mathrm{U} / \mathrm{mL})$, endoglucanase $(2.28 \mathrm{U} / \mathrm{mL})$, and $\beta$-glucosidase $(1.99 \mathrm{U} / \mathrm{mL})$, where peptone also produces the second most cellulase producing nitrogen source by Trichoderma sp. (Table 4). It was reported that good cellulase yield can be obtained with ammonium compound as the nitrogen source. Though the addition of organic nitrogen sources such as beef extract and peptone resulted in increased growth and enzyme 
TABLE 3: Effect of carbon sources (\%) on cellulase production (U/mL) by Trichoderma sp.

\begin{tabular}{|c|c|c|c|c|c|c|c|c|}
\hline \multicolumn{2}{|c|}{ Conc. (\%) } & \multicolumn{2}{|r|}{0.5} & \multirow{2}{*}{$\frac{1.0}{2.31 \pm 0.08}$} & \multirow{2}{*}{$\begin{array}{c}1.5 \\
1.71 \pm 0.06\end{array}$} & \multirow{2}{*}{$\begin{array}{c}2.0 \\
0.97 \pm 0.05\end{array}$} & \multirow{2}{*}{$\begin{array}{c}2.5 \\
0.62 \pm 0.04\end{array}$} & \multirow{2}{*}{$\begin{array}{c}3.0 \\
0.26 \pm 0.02\end{array}$} \\
\hline & & 1 & $0.68 \pm 0.04$ & & & & & \\
\hline & Glucose & 2 & $0.49 \pm 0.03$ & $1.93 \pm 0.07$ & $1.43 \pm 0.05$ & $0.98 \pm 0.04$ & $0.74 \pm 0.04$ & $0.34 \pm 0.03$ \\
\hline & & 3 & $0.41 \pm 0.02$ & $1.91 \pm 0.09$ & $1.67 \pm 0.07$ & $0.91 \pm 0.05$ & $0.55 \pm 0.04$ & $0.37 \pm 0.03$ \\
\hline & & 1 & $0.44 \pm 0.05$ & $1.89 \pm 0.08$ & $1.61 \pm 0.08$ & $1.26 \pm 0.06$ & $0.81 \pm 0.05$ & $0.63 \pm 0.04$ \\
\hline & Maltose & 2 & $0.35 \pm 0.04$ & $1.91 \pm 0.07$ & $1.46 \pm 0.05$ & $0.88 \pm 0.05$ & $0.53 \pm 0.04$ & $0.32 \pm 0.03$ \\
\hline & & 3 & $0.47 \pm 0.05$ & $1.90 \pm 0.08$ & $1.63 \pm 0.06$ & $1.10 \pm 0.05$ & $0.72 \pm 0.04$ & $0.39 \pm 0.03$ \\
\hline & & 1 & $0.67 \pm 0.05$ & $2.68 \pm 0.07$ & $2.21 \pm 0.08$ & $1.55 \pm 0.05$ & $0.84 \pm 0.04$ & $0.44 \pm 0.03$ \\
\hline \multirow[t]{8}{*}{ Different carbon sources } & Sucrose & 2 & $0.50 \pm 0.06$ & $2.17 \pm 0.07$ & $1.51 \pm 0.06$ & $0.86 \pm 0.05$ & $0.64 \pm 0.04$ & $0.31 \pm 0.03$ \\
\hline & & 3 & $0.42 \pm 0.04$ & $2.06 \pm 0.08$ & $1.51 \pm 0.08$ & $0.90 \pm 0.06$ & $0.74 \pm 0.05$ & $0.31 \pm 0.04$ \\
\hline & & 1 & $0.41 \pm 0.05$ & $1.99 \pm 0.08$ & $1.71 \pm 0.07$ & $1.11 \pm 0.07$ & $0.83 \pm 0.06$ & $0.56 \pm 0.04$ \\
\hline & Cellulose & 2 & $0.70 \pm 0.06$ & $1.89 \pm 0.07$ & $1.33 \pm 0.07$ & $0.94 \pm 0.06$ & $0.68 \pm 0.05$ & $0.55 \pm 0.04$ \\
\hline & & 3 & $0.35 \pm 0.04$ & $2.08 \pm 0.07$ & $1.81 \pm 0.07$ & $0.92 \pm 0.06$ & $0.71 \pm 0.05$ & $0.59 \pm 0.04$ \\
\hline & & 1 & $0.41 \pm 0.03$ & $1.94 \pm 0.06$ & $1.71 \pm 0.05$ & $0.63 \pm 0.05$ & $0.42 \pm 0.04$ & $0.32 \pm 0.03$ \\
\hline & Carboxymethyl cellulose & 2 & $0.37 \pm 0.04$ & $1.72 \pm 0.05$ & $1.63 \pm 0.06$ & $0.85 \pm 0.05$ & $0.64 \pm 0.04$ & $0.38 \pm 0.04$ \\
\hline & & 3 & $0.41 \pm 0.05$ & $1.88 \pm 0.07$ & $1.73 \pm 0.08$ & $1.41 \pm 0.06$ & $0.86 \pm 0.05$ & $0.43 \pm 0.04$ \\
\hline
\end{tabular}

1-FPase, 2-CMCase \& 3- $\beta$-glucosidase.

TABLE 4: Effect of nitrogen sources $(\%)$ on cellulase production $(\mathrm{U} / \mathrm{mL})$ by Trichoderma sp.

\begin{tabular}{|c|c|c|c|c|c|c|c|c|}
\hline \multicolumn{2}{|c|}{ Conc. $(\%)$} & \multicolumn{2}{|r|}{0.5} & \multirow{2}{*}{$\frac{1.0}{2.21 \pm 0.08}$} & \multirow{2}{*}{$\frac{1.5}{1.89 \pm 0.07}$} & \multirow{2}{*}{$\frac{2.0}{1.52 \pm 0.07}$} & \multirow{2}{*}{$\frac{2.5}{0.91 \pm 0.06}$} & \multirow{2}{*}{$\frac{3.0}{0.53 \pm 0.04}$} \\
\hline & & 1 & $0.31 \pm 0.04$ & & & & & \\
\hline & Peptone & 2 & $0.32 \pm 0.05$ & $1.93 \pm 0.07$ & $1.62 \pm 0.06$ & $0.84 \pm 0.06$ & $0.63 \pm 0.05$ & $0.48 \pm 0.04$ \\
\hline & & 3 & $0.37 \pm 0.03$ & $1.94 \pm 0.06$ & $1.71 \pm 0.07$ & $0.91 \pm 0.06$ & $0.46 \pm 0.05$ & $0.39 \pm 0.05$ \\
\hline & & 1 & $0.39 \pm 0.04$ & $2.40 \pm 0.08$ & $1.78 \pm 0.07$ & $0.92 \pm 0.06$ & $0.58 \pm 0.06$ & $0.43 \pm 0.04$ \\
\hline & Yeast extract & 2 & $0.31 \pm 0.03$ & $2.28 \pm 0.07$ & $1.87 \pm 0.07$ & $0.92 \pm 0.05$ & $0.62 \pm 0.05$ & $0.43 \pm 0.03$ \\
\hline & & 3 & $0.27 \pm 0.04$ & $1.99 \pm 0.07$ & $1.72 \pm 0.07$ & $1.41 \pm 0.06$ & $0.75 \pm 0.05$ & $0.55 \pm 0.04$ \\
\hline & & 1 & $0.41 \pm 0.05$ & $1.93 \pm 0.07$ & $1.69 \pm 0.07$ & $1.21 \pm 0.06$ & $0.93 \pm 0.05$ & $0.51 \pm 0.04$ \\
\hline \multirow[t]{8}{*}{ Different nitrogen sources } & Beef extract & 2 & $0.32 \pm 0.05$ & $1.79 \pm 0.07$ & $1.62 \pm 0.06$ & $0.93 \pm 0.06$ & $0.60 \pm 0.05$ & $0.42 \pm 0.05$ \\
\hline & & 3 & $0.22 \pm 0.04$ & $1.95 \pm 0.05$ & $1.71 \pm 0.05$ & $0.96 \pm 0.04$ & $0.61 \pm 0.04$ & $0.33 \pm 0.03$ \\
\hline & & 1 & $0.24 \pm 0.04$ & $1.73 \pm 0.06$ & $1.47 \pm 0.06$ & $0.89 \pm 0.05$ & $0.64 \pm 0.04$ & $0.30 \pm 0.04$ \\
\hline & Ammonium nitrate & 2 & $0.19 \pm 0.03$ & $1.64 \pm 0.06$ & $1.23 \pm 0.06$ & $0.82 \pm 0.05$ & $0.67 \pm 0.05$ & $0.31 \pm 0.04$ \\
\hline & & 3 & $0.15 \pm 0.03$ & $1.69 \pm 0.06$ & $1.44 \pm 0.06$ & $0.88 \pm 0.04$ & $0.63 \pm 0.04$ & $0.28 \pm 0.03$ \\
\hline & & 1 & $0.31 \pm 0.03$ & $1.76 \pm 0.07$ & $1.53 \pm 0.06$ & $0.99 \pm 0.06$ & $0.65 \pm 0.04$ & $0.41 \pm 0.04$ \\
\hline & Sodium nitrate & 2 & $0.22 \pm 0.03$ & $1.56 \pm 0.05$ & $1.44 \pm 0.05$ & $0.84 \pm 0.04$ & $0.67 \pm 0.04$ & $0.51 \pm 0.03$ \\
\hline & & 3 & $0.11 \pm 0.03$ & $1.74 \pm 0.05$ & $1.11 \pm 0.05$ & $0.68 \pm 0.05$ & $0.54 \pm 0.04$ & $0.31 \pm 0.03$ \\
\hline
\end{tabular}

1-FPase, 2-CMCase \& 3- $\beta$-glucosidase.

production, as was reported before, they were not an effective replacement for inorganic nitrogen sources because of their higher cost [32].

3.2.6. Effect of Municipal Solid Waste Residue in Enzyme Production. In the present investigation, municipal solid waste residue was used as a cheap and easily available carbon source for cellulase enzyme production. The results revealed that MSW residue $(4.0 \%)$ was the best carbon substrate for exoglucanase $(1.19 \mathrm{U} / \mathrm{mL})$, endoglucanase $(1.504 \mathrm{U} / \mathrm{mL})$, and $\beta$-glucosidase $(1.39 \mathrm{U} / \mathrm{mL})$ by $A$. niger as shown in Figure 4, while in case of Trichoderma sp. 4.0\% MSW residue was best for cellulase (exoglucanase $(1.77 \mathrm{U} / \mathrm{mL}$ ), endoglucanase $(1.95 \mathrm{U} / \mathrm{mL})$, and $\beta$-glucosidase $(1.66 \mathrm{U} / \mathrm{mL})$ ) enzyme production (Figure 8 ). These results were confirmed by the results of [33]. This variation may be attributed to the chemical nature and nutrient availability of the used substrates.

\section{Conclusions}

In this investigation, the culturing of $A$. niger and Trichoderma sp. proved to be an excellent source for the enzymes production. In the present study, these cultures produced an amount of enzyme 40 to $60 \%$ higher than other fungi. Municipal solid waste in the form of cellulose which is the most abundant renewable biomass in the biosphere has been shown to be used in the production of valuable products by A. niger and Trichoderma sp. Municipal solid waste residue could provide an economical advantage as a solid substrate 


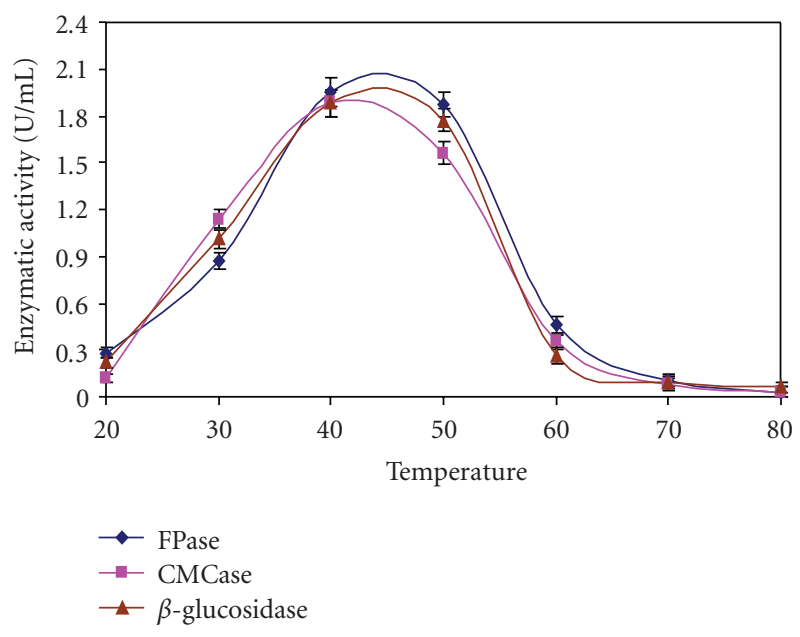

Figure 6: Effect of temperature on cellulase production $(\mathrm{U} / \mathrm{mL})$ by Trichoderma sp.

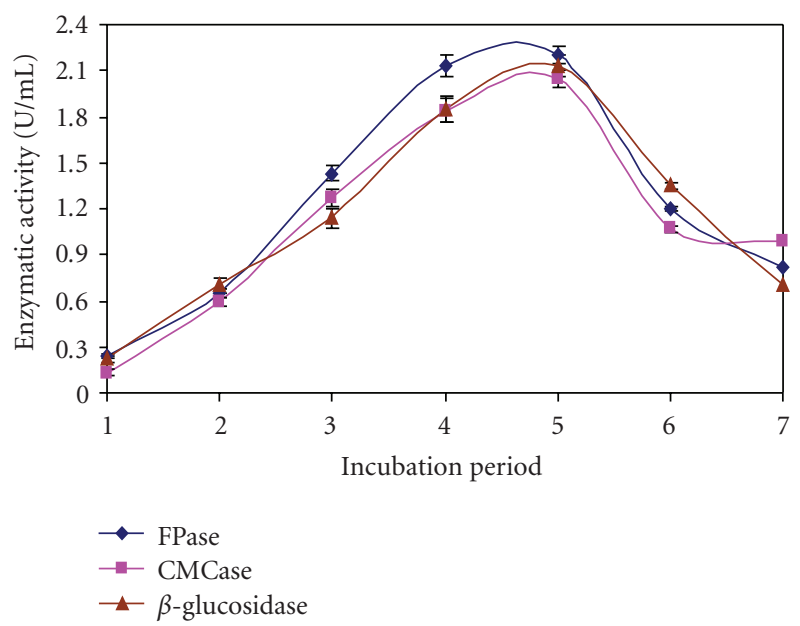

FIGURE 7: Effect of incubation period on cellulase production (U/mL) by Trichoderma sp.

as well as a carbon source for production of cellulase enzyme by using fungus strain, $A$. niger and Trichoderma sp. Thus, a simplified medium containing municipal solid waste residue supplemented with simple salts proved to be cost effective substrate for cellulase production. Mixed culture combinations have the ability to utilize the substrates as energy sources better than highly versatile pure cultures. Further investigations are required to make use of the full potential of these organisms for cellulase production by employing genetic, biochemical, and microbial engineering techniques.

\section{Acknowledgments}

The authors are thankful to M. P. Pollution Control Board Bhopal and Head, Department of Biological Sciences, R. D. University, Jabalpur, for laboratory facilities. Ministry

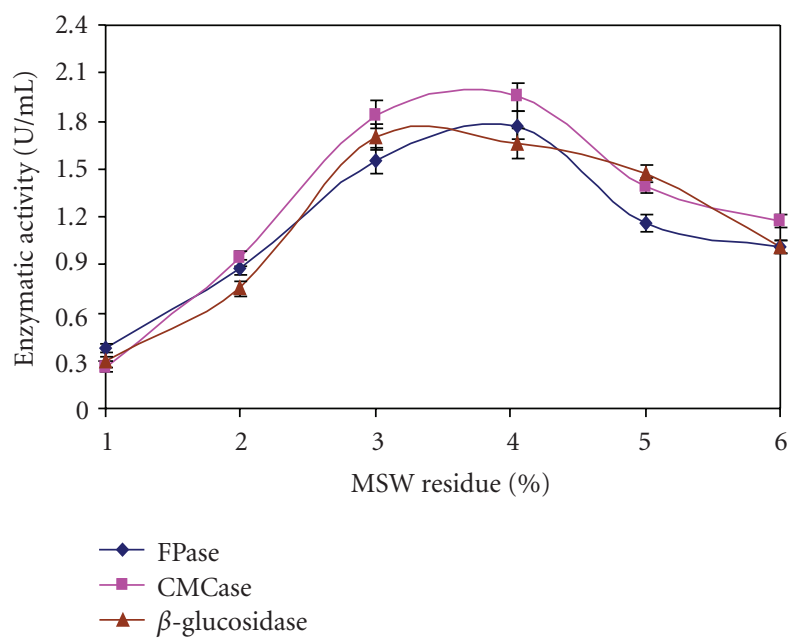

Figure 8: Effect of MSW residue on cellulase production (U/mL) by Trichoderma sp.

of Environment and Forest New Delhi is also thankfully acknowledged for financial support.

\section{References}

[1] B. H. Lee, B. K. Kim, Y. J. Lee, C. H. Chung, and J. W. Lee, "Industrial scale of optimization for the production of carboxymethylcellulase from rice bran by a marine bacterium, Bacillus subtilis subsp. subtilis A-53," Enzyme and Microbial Technology, vol. 46, no. 1, pp. 38-42, 2010.

[2] D. S. Rani and K. Nand, "Production of thermostable cellulase-free xylanase by Clostridium absonum CFR-702," Process Biochemistry, vol. 36, no. 4, pp. 355-362, 2000.

[3] S. Jagtap and M. Rao, "Purification and properties of a low molecular weight $1,4-\beta$-D-glucan glucohydrolase having one active site for carboxymethyl cellulose and xylan from an alkalothermophilic Thermomonospora sp," Biochemical and Biophysical Research Communications, vol. 329, no. 1, pp. 111116, 2005.

[4] R. Guo, M. Ding, S. L. Zhang, G. J. Xu, and F. K. Zhao, "Molecular cloning and characterization of two novel cellulase genes from the mollusc Ampullaria crossean," Journal of Comparative Physiology B, vol. 178, no. 2, pp. 209-215, 2008.

[5] K. S. Siddiqui, A. A. N. Saqib, M. H. Rashid, and M. I. Rajoka, "Carboxyl group modification significantly altered the kinetic properties of purified carboxymethylcellulase from Aspergillus niger," Enzyme and Microbial Technology, vol. 27, no. 7, pp. 467-474, 2000.

[6] M. Schülein, "Protein engineering of cellulases," Biochimica et Biophysica Acta, vol. 1543, no. 2, pp. 239-252, 2000.

[7] R. Duenas, R. P. Tengerdy, and M. Gutierrez-Correa, "Cellulase production by mixed fungi in solid-substrate fermentation of bagasse," World Journal of Microbiology and Biotechnology, vol. 11, no. 3, pp. 333-337, 1995.

[8] V. S. Bisaria and T. K. Ghose, "Biodegradation of cellulosic materials: substrates, microorganisms, enzymes and products," Enzyme and Microbial Technology, vol. 3, no. 2, pp. 90104, 1981.

[9] M. Linko, "An evolution of enzymatic hydrolysis of cellulosic materials," Advances in Biochemical Engineering, vol. 5, pp. 2541, 1977. 
[10] D. M. Updegraff, "Utilization of cellulose from waste paper by Myrothecium verrucaria," Biotechnology and Bioengineering, vol. 13, no. 1, pp. 77-97, 1971.

[11] B. ven Hofsten, Microbial Conversion of Cellulosic Waste Products Waste Recovery by Microorganism, UNESCO, Kualalumpur, Malaysia, 1972.

[12] S. P. Gautam, P. S. Bundela, A. K. Pandey, M. K. Awasthi, and S. Sarsaiya, "Composting of municipal solid waste of Jabalpur City," Global Journal of Environmental Research, vol. 4, pp. 4346, 2010.

[13] A. E. Hamphery, A. Moreira, W. Armiger, and D. Zabriskie, "Production of single cell protein from cellulose wastes," Biotechnology \& Bioengineering Symposium, vol. 7, pp. 45-64, 1977.

[14] G. Immanuel, R. Dhanusha, P. Prema, and A. Palavesam, "Effect of different growth parameters on endoglucanase enzyme activity by bacteria isolated from coir retting effluents of estuarine environment," International Journal of Environmental Science and Technology, vol. 3, no. 1, pp. 25-34, 2006.

[15] K. M. Bischoff, A. P. Rooney, X. L. Li, S. Liu, and S. R. Hughes, "Purification and characterization of a family 5 endoglucanase from a moderately thermophilic strain of Bacillus licheniformis," Biotechnology Letters, vol. 28, no. 21, pp. 1761-1765, 2006.

[16] P. S. Chahal, D. S. Chahal, and G. Andre, "Cellulase production profile of Trichoderma reesei on different cellulosic substrates at various $\mathrm{pH}$ levels," Journal of Fermentation and Bioengineering, vol. 74, no. 2, pp. 126-128, 1992.

[17] S. J. B. Duff and W. D. Murray, "Bioconversion of forest products industry waste cellulosics to fuel ethanol: a review," Bioresource Technology, vol. 55, no. 1, pp. 1-33, 1996.

[18] K. Reczey, Z. Szengyel, R. Eklund, and G. Zacchi, "Cellulase production by T. reesei," Bioresource Technology, vol. 57, no. 1, pp. 25-30, 1996.

[19] P. F. Omojasola and O. P. Jilani, "Cellulase production by Trichoderma longi, Aspergillus niger and Saccharomyces cerevisae cultured on waste materials from orange," Pakistan Journal of Biological Sciences, vol. 11, no. 20, pp. 2382-2388, 2008.

[20] J. H. J. R. Makoi and P. A. Ndakidemi, "Selected soil enzymes: examples of their potential roles in the ecosystem," African Journal of Biotechnology, vol. 7, no. 3, pp. 181-191, 2008.

[21] L. Hankin and S. L. Anagnostakis, "Solid media containing carboxymethylcellulose to detect $\mathrm{C}_{x}$ cellulase activity of micro organisms," Journal of General Microbiology, vol. 98, no. 1, pp. 109-115, 1977.

[22] A. A. Sherief, A. B. El-Tanash, and N. Atia, "Cellulase production by Aspergillus fumigatus grown on mixed substrate of rice straw and wheat bran," Research Journal of Microbiology, vol. 5, no. 3, pp. 199-211, 2010.

[23] G. L. Miller, "Use of dinitrosalicylic acid reagent for determination of reducing sugar," Analytical Chemistry, vol. 31, no. 3, pp. 426-428, 1959.

[24] S. B. Pointing, "Qualitative methods for the determination of lignocellulolytic enzyme production by tropical fungi," Fungal Diversity, vol. 2, pp. 17-33, 1999.

[25] L. R. Lynd, P. J. Weimer, W. H. van Zyl, and I. S. Pretorius, "Microbial cellulose utilization: fundamentals and biotechnology," Microbiology and Molecular Biology Reviews, vol. 66, no. 3, pp. 506-577, 2002.

[26] S. Murao, R. Sakamoto, and M. Arai, "Cellulase of Aspergillus aculeatus," in Methods in Enzymology, W. A. Wood and S. T. Kellog, Eds., vol. 160, pp. 275-284, Academic Press, London, UK, 1988.
[27] W. Lu, D. Li, and Y. Wu, "Influence of water activity and temperature on xylanase biosynthesis in pilot-scale solid-state fermentation by Aspergillus sulphureus," Enzyme and Microbial Technology, vol. 32, no. 2, pp. 305-311, 2003.

[28] S. W. Kang, Y. S. Park, J. S. Lee, S. I. Hong, and S. W. Kim, "Production of cellulases and hemicellulases by Aspergillus niger KK2 from lignocellulosic biomass," Bioresource Technology, vol. 91, no. 2, pp. 153-156, 2004.

[29] S. V. Nochur, M. F. Roberts, and A. L. Demain, "True cellulase production by clostridium thermocellum grown on different carbon sources," Biotechnology Letters, vol. 15, no. 6, pp. 641646, 1993.

[30] N. Mandels and E. T. Reese, "Induction of cellulase in fungi by cellobiose," Journal of Bacteriology, vol. 79, no. 6, pp. 816-826, 1960.

[31] B. O. Solomon, B. Amigun, E. Betiku, T. V. Ojumu, and S. K. Layokun, "Optimization of cellulase production by Aspergillus flavus Linn isolates NSPR 101 grown on bagass," Journal of Nigerian Society of Chemical Engineering, vol. 16, pp. 61-68, 1997.

[32] S. Tao, L. Beihui, L. Zuohu, and L. Deming, "Effects of air pressure amplitude on cellulase productivity by Trichoderma viride SL-1 in periodic pressure solid state fermenter," Process Biochemistry, vol. 34, no. 1, pp. 25-29, 1999.

[33] M. A. M. Abo-State, A. I. Hammad, M. Swelin, and R. B. Gannam, "Enhanced production of cellulases by Aspergillus spp. isolated from agriculture wastes by solid state fermentation," American-Eurasian Journal of Agricultural \& Environmental Science, vol. 8, pp. 402-410, 2010. 

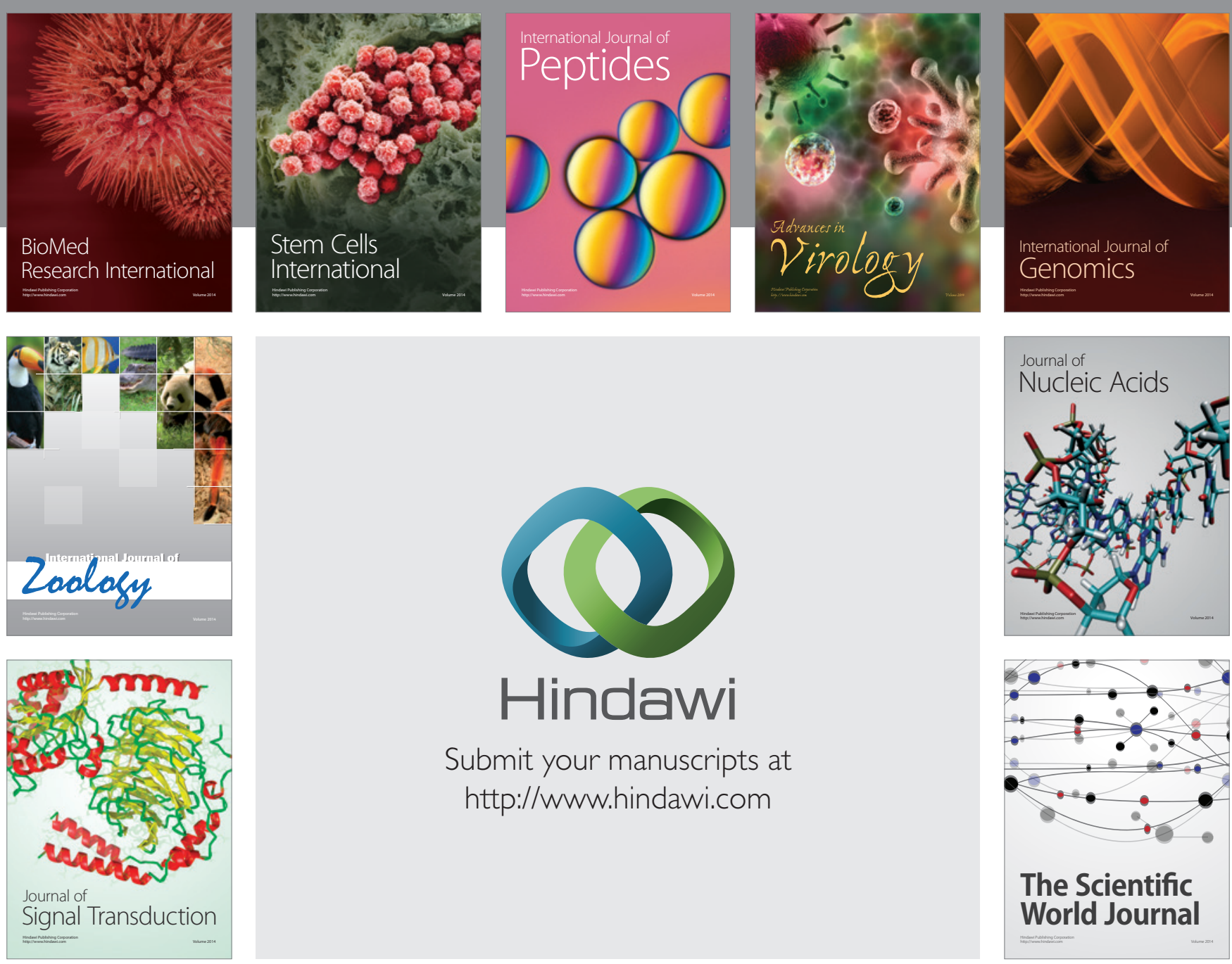

Submit your manuscripts at

http://www.hindawi.com
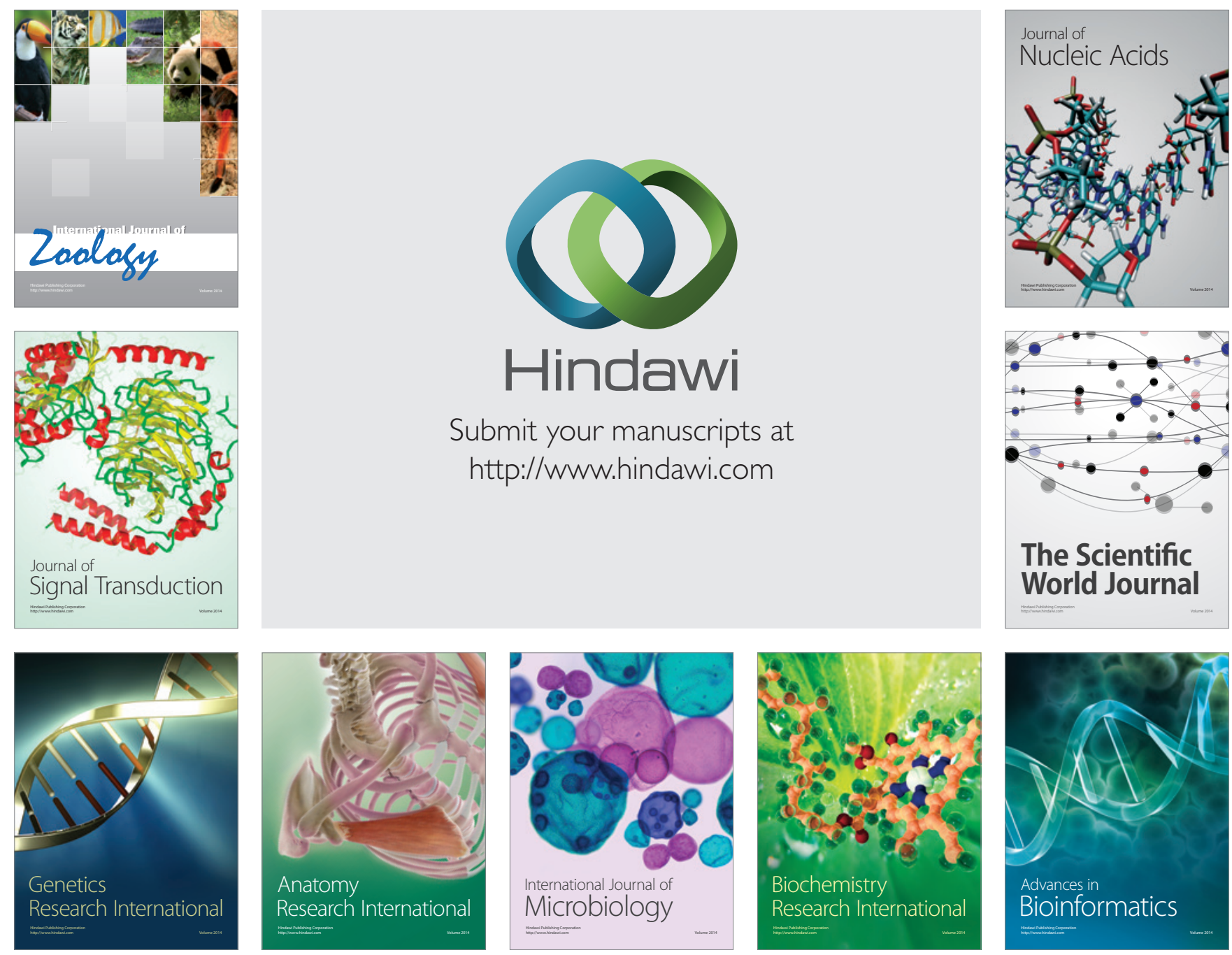

The Scientific World Journal
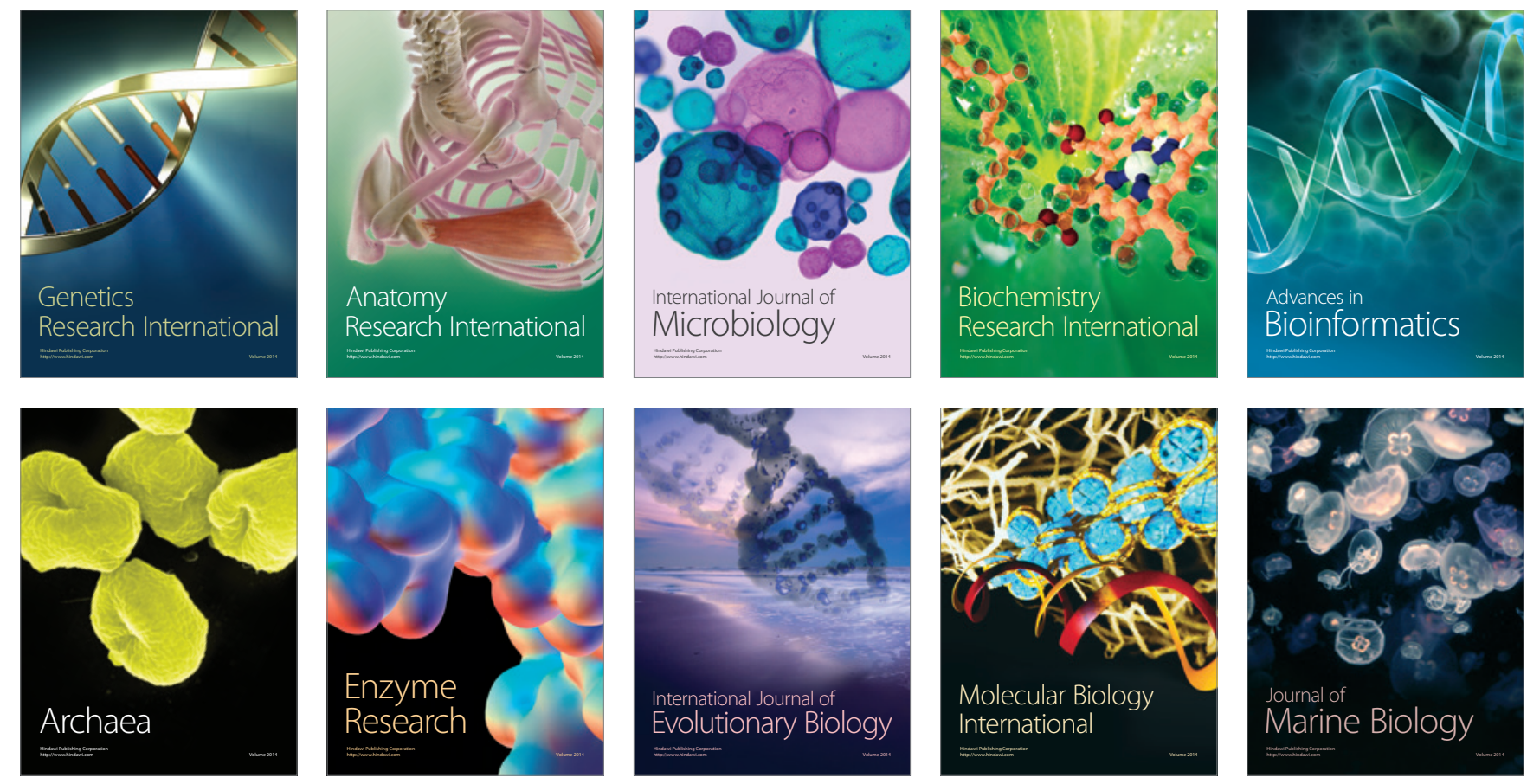